\title{
ROBUST GLOBAL SLIDING MODEL CONTROL FOR WATER-HULL-PROPULSION UNIT INTERACTION SYSTEMS - PART 1: SYSTEM BOUNDARY IDENTIFICATION
}

\author{
Zhixiong Li, Xinping Yan, Li Qin, Kai Cheng, J. T. Xing
}

Original scientific paper

Unexpected severe hull deformation caused by the wave loads would significantly influence the dynamical behaviours of the propulsion system in large scale ships, resulting in degradation of the ship control performance. A new global sliding model control (GSMC) for marine water-hull-propulsion unit systems is proposed to obtain more accurate control performance in this paper. The GSMC was firstly employed to establish the marine propulsion control model with nonlinear uncertainties. In the GSMC model, the saturation function method is applied to eliminate chattering on the sliding surface. Then the Lyapunov stability criterion is adopted to confirm the stability of the control system. Following, for the first time, the boundary problem of the nonlinear model uncertainties were investigated quantitatively. The bounded nonlinear model uncertainties required in the proposed GSMC model, involving engine torque loss / variations, power transfer for various load conditions and shaft rotational speeds, were derived based on the experiments carried out on a marine shaft-line test-bed of the integrated propulsion system as well as a sea trial implemented for a running bulk carrier. An upper boundary of $1,85 \%$ for the model uncertainty has been obtained, which would be introduced into the GSMC for the integrated marine propulsion system to derive the total control law realising the robust control of the system.

Keywords: global sliding model control; nonlinear control model; marine propulsion system; uncertainties in marine propulsion system; water-hullprolusion unit interactions;

\section{Upravljanje izdržljivim globalnim kliznim modelom za interakcijske sustave voda-trup-pogonska jedinica - Dio 1: Prepoznavanje granice sustava}

Izvorni znanstveni članak

Nepredviđene jake deformacije trupa uzrokovane težinom valova mogle bi značajno utjecati na dinamičko ponašanje pogonskog sustava velikih brodova, rezultirajući slabljenjem upravljačke funkcije broda. U ovom se radu predlaže upravljanje novim globalnim kliznim modelom (GSMC) za brodske sustave voda-trup-pogonska jedinica u svrhu poboljšanja upravljačkih performansi. Taj GSMC najprije je primijenjen u razvijanju modela za upravljanje brodskim pogonom s nelinearnim nesigurnostima. U GSMC modelu primijenjena je metoda funkcije zasićenja za isključenje podrhtavanja na kliznoj površini. Zatim je pomoću Lyapunova kriterija stabilnosti potvrđena stabilnost upravljačkog sustava. Po prvi puta, granični problem nesigurnosti nelinearnog modela kvantitativno je istražen. Nesigurnosti graničnog nelinearnog modela potrebne u predloženom GSMC modelu, uključujući gubitak /varijacije zakretnog momenta motora, prijenos energije za različite uvjete opterećenja i brzine rotacije osovine, dobivene su na temelju eksperimenata provedenih na liniji brodski osovinski vod - probni stol integriranog pogonskog sustava kao i pokusne plovidbe na moru broda za prijevoz rasutog tereta. Postignuta je gornja granica od $1,85 \%$ za nesigurnost modela, i ona bi se trebala unijeti u GSMC za integrirani brodski pogonski sustav kako bi se izveo ukupni upravljački zakon za realizaciju izdržljivog upravljanja sustava

Ključne riječi: interakcije voda-trup-pogon; nelinearni upravljački model; nesigurnosti u sustavu brodskog pogona; sustav brodske propulzije (pogona); upravljanje globalnim kliznim modelom

\section{Introduction}

The control of marine propulsion systems considering hull deformations has attracted a great attention due to the important effects of the propulsion system - hull interactions on the dynamic characteristic of the propulsion unit. Designs of marine propulsion systems are usually completed using an empirical process model without considering water - propeller - hull interactions $[1,2]$. The rapid increase of ship sizes has made this type of coupling analysis extremely necessary for safety ship designs and operations. There are many difficulties for a traditional Proportional Integral Derivative (PID) controller to obtain the desired performance of marine propulsion systems $[1,3]$ while involving some inevitable uncertainties caused by the complex water - propeller hull interactions. As a result of this, the robust control strategy has been studied to obtain an effective control performance of marine propulsion systems considering internal / externals uncertainties and disturbances [ $4 \div 7]$.

Interactions between the water, hull and propulsion system are the main sources of the model uncertainties imposed into the propulsion systems [8], which causes strong nonlinear characteristics governing marine propulsion systems $[1 \div 3]$. Advanced nonlinear control methodologies with nonlinear objectives have been proposed, and the nonlinear compensation approaches have been proven to be effective in both track-keeping and course-changing maneuvers of marine vessels [9]. These nonlinear control methods include back-stepping schemes [10, 11], state feedbacks $[12,13]$, output feedbacks $[14,15]$, etc. However, many of these nonlinear controllers belong to a model-based technique. Therefore, a big challenge research topic is generated for them to deal with unbounded modelling inaccuracies [1]. For this purpose, a sliding mode control (SMC) technique [16] was developed to provide a robust control for a nonlinear system without knowing its details of nonlinearities [4].This is because the SMC only uses the upper bounds of the modelling inaccuracies to design robust controllers [17]. Both structured and unstructured uncertainties could be compensated efficiently by these controllers [18].

The SMC has been widely used for robust control of nonlinear systems with uncertainties [19] due to its fast responses and robustness to any variations of system parameters [4]. Although the SMC does not require detailed information of the system uncertainties, it needs a good estimation of the uncertainty bound at the outset of the design for an effective stable control performance of the nonlinear system. For marine propulsion systems, such a bound cannot be easily estimated, so that most research reports $[5,6,20,21,22]$ assumed a random 
uncertainty without its boundary definition. For example, combining the model following control (MFC) and internal model control (IMC) techniques, Brzózka [5] proposed an approach to control the ship engine speed. Numerical analysis has shown a high effectiveness of MFC/IMC approach for speed-keeping and speedchanging in the ship regulation. Xiros [6] presented an adaptive PID controller using $\mathrm{H} \infty$-norm tuning to make the ship governors against the propeller load fluctuation. Zhang and Ren $[20 \div 22]$ designed an adaptive neural network based ship speed regulating simulation system to compensate the system uncertainties. To be cited but too many, the system uncertainties used in the reported methods are chosen as random, and therefore the uncertainty boundaries required for SMC are not investigated. Furthermore, in the base of our knowledge, some relevant studies considering the effects of uncertain parameters on the modelling of the marine propulsion systems caused by interactions between the water, hull and propulsion unit have not been found.

In order to develop a practicable tool for a high performance control of the marine propulsion system, it is crucial to investigate the boundaries of the model uncertainties of the marine propulsion system caused by interactions between the water, hull and propulsion unit, from which a good estimation of the upper boundary of the system uncertainties can be obtained to design a stable and effective SMC controller for the robust control of the marine propulsion system. This paper intends to address the mentioned issue by developing a global sliding mode controller (GSMC) for the marine propulsion systems with bounded nonlinear model uncertainties. The upper boundary of the dynamical uncertainties of the system involving the water-hull-propulsion unit interactions is investigated and obtained based on the marine propulsion system test-bed experiments and sea trials. A new method of GSMC accommodating the model uncertainties for marine propulsion systems is proposed and studied. Numerical studies using the real bulk carrier parameters are completed to demonstrate the efficiency of the proposed control system.

\section{Design of global sliding model controller}

The operation condition of the marine propulsion may be influenced significantly by the coupled effect between the water and hull. The wave loads and the hull deformations will induce severe vibration and large deformation of the propulsion system [8]. Consequently, the dynamics of the marine propulsion system present strong nonlinear uncertainties [1]. In order to compensate the system uncertainties, the GSMC is introduced into the robust control of the marine propulsion system.

\subsection{Controller design}

The marine propulsion model subjected to external nonlinear uncertainties has been discussed in our previous work $[1,2]$. The model with nonlinear uncertainties can be expressed as [1]

$$
2 \pi J \frac{M_{\mathrm{R}}}{\omega_{\mathrm{R}} \cdot K} \frac{d \omega_{\mathrm{r}}}{\mathrm{d} t}+\omega_{\mathrm{r}}=\frac{\left(1-k_{\mathrm{s}}\right) L_{\mathrm{R}}}{\omega_{\mathrm{R}} \cdot K} \frac{\partial M_{\mathrm{e}}}{\partial L_{\mathrm{r}}} L_{\mathrm{r}}-\frac{1}{\omega_{\mathrm{R}} \cdot K} \frac{\partial M_{\mathrm{p}}}{\partial \zeta} \zeta
$$

where, $M_{\mathrm{R}}, M_{\mathrm{e}}$ and $M_{\mathrm{p}}$ are the rated engine torque, engine output torque, and propeller load torque, respectively; $\omega_{\mathrm{R}}$ and $\omega_{\mathrm{r}}$ are the rated engine rotational speed and its relative variation; $L_{\mathrm{R}}$ and $L_{\mathrm{r}}$ are the maximum stroke of the fuel pump rack and its relative variation; $K=\frac{\partial M_{\mathrm{p}}}{\partial \omega_{\mathrm{r}}}-2\left(1-k_{\mathrm{s}}\right) \frac{\partial M_{\mathrm{e}}}{\partial \omega_{\mathrm{r}}} ; \quad J$ denotes the rotational inertia of the propulsion, $k_{\mathrm{s}}$ is the engine output torque loss, and $\zeta$ denotes the propeller load fluctuation. In the stable operation process, the terms of $K, \frac{\partial M_{\mathrm{e}}}{\partial L_{\mathrm{r}}}$ and $\frac{\partial M_{\mathrm{p}}}{\partial \zeta}$

in (1) can be approximated according to the engine operation characteristic curves [21]. It can be seen in (1) that the uncertain parameters $k_{\mathrm{s}}$ and $\zeta$ may be the source of system uncertainties. Due to the influence of $k_{\mathrm{s}}$ and $\zeta$, the engine output torque and the propeller load torque will suffer from variations according to items $\frac{\left(1-k_{\mathrm{s}}\right) L_{\mathrm{R}}}{\omega_{\mathrm{R}} K} \frac{\partial M_{\mathrm{e}}}{\partial L_{\mathrm{r}}} L_{\mathrm{r}}$ and $\frac{1}{\omega_{\mathrm{R}} K} \frac{\partial M_{\mathrm{p}}}{\partial \zeta} \zeta$ in (1). As a consequence, the dynamics of the propulsion will be influenced by the coupled effect presented in item $2 \pi J \frac{M_{\mathrm{R}}}{\omega_{\mathrm{R}} K} \frac{\mathrm{d} \omega_{\mathrm{r}}}{\mathrm{d} t}$ in (1). Actually the parameters $k_{\mathrm{s}}$ and $\zeta$ are determined by the wave loads outside the ship, which means all the variations and uncertainties of the propulsion system are caused or induced by the external stochastic excitations, through the interaction of the water, ship hull and propulsion system. This coupled effect between the water, ship hull and propulsion system attributes to the particular operation environment of the ship in the sea.

In order to design the control system for the marine propulsion system, (1) need to be rewritten in the form of state-space. Since in the stable operation process the terms of $K, \frac{\partial M_{\mathrm{e}}}{\partial L_{\mathrm{r}}}$ and $\frac{\partial M_{\mathrm{p}}}{\partial \zeta}$ in (1) can be approximated [21], we firstly rewrite (1) into the following form:

$$
\frac{\mathrm{d} \omega_{\mathrm{r}}}{\mathrm{d} t}+\frac{1}{K_{1}} \omega_{\mathrm{r}}=\frac{K_{2}\left(1-k_{\mathrm{s}}\right)}{K_{1}} L_{\mathrm{r}}-\frac{K_{3}}{K_{1}} \zeta
$$

Where, $\quad K_{1}=2 \pi J \frac{M_{\mathrm{R}}}{\omega_{\mathrm{R}} K}, \quad K_{2}=\frac{L_{\mathrm{R}}}{\omega_{\mathrm{R}} K} \frac{\partial M_{\mathrm{e}}}{\partial L_{\mathrm{r}}}, \quad$ and $K_{3}=\frac{1}{\omega_{\mathrm{R}} K} \frac{\partial M_{\mathrm{p}}}{\partial \zeta}$.

Let the engine speed be $\omega$ in the stable operation process to replace $\omega_{\mathrm{R}}$, since $\omega_{\mathrm{r}}$ is the variation of the engine rotational speed, i.e., $\omega_{\mathrm{r}}=\dot{\omega}$, (2) could be rewritten as

$\ddot{\omega}+\frac{1}{K_{1}} \dot{\omega}=\frac{K_{2}\left(1-k_{\mathrm{s}}\right)}{K_{1}} L_{\mathrm{r}}-\frac{K_{3}}{K_{1}} \zeta$.

One can notice that to a certain degree the term of $K_{1}$ imposes uncertainty on the propulsion system due to the 
existence of term $k_{\mathrm{s}}$ in $K$. Similarly, the term $\frac{K_{2}}{K_{1}}$ and $\frac{K_{3}}{K_{1}}$ address uncertainties on the fuel injection $L_{\mathrm{r}}$ and the propeller torque $\zeta$, respectively. No matter how these uncertainties could influence the marine propulsion system, (3) has taken the interactions between the water, hull and propulsion unit into account to model the dynamics of the propulsion system as much as accurate. For the purpose of simply analysis, we redefine the dynamic model (3) into a more universal framework as

$\ddot{\omega}+p(t) \dot{\omega}=h(t)[Q+c(t)]$

where, $Q$ denotes the oil injection; $p(t)>0$ denotes the system uncertainty subjecting to the propulsion; $h(t)>0$ denotes the system uncertainty subjecting to the hull; $c(t)>0$ denotes the system uncertainty subjecting to wave loads. The control problem in (4) is that the engine speed $\omega$ is controlled to follow a specific speed reference by actuating the oil injection $Q$. Usually, the boundaries of $p(t)$ and $h(t)$ could be predicted by prior experience and professional knowledge while the boundaries of $c(t)$ could be estimated by access the variation of the engine output power / torque.

Assume

$$
\left\{\begin{array}{l}
b_{1} \leq p^{-1}(t) \leq b_{2} \\
a_{1} \leq p^{-1}(t) h(t) \leq a_{2} \\
c(t)<C
\end{array}\right.
$$

where, $a$ and $b$ are boundaries of uncertainties subjecting to the propulsion and hull, respectively; $c$ is the upper boundary of the external wave loads.

Let the speed tracking error be

$e=\omega-\tilde{\omega}$

where, $\tilde{\omega}$ is the speed reference. The global sliding model surface then can be designed as

$s=\dot{e}+\lambda e-f(t)$

where, $\lambda$ needs to be specified and the global sliding model function $f(t)$ subjects to

$$
\left\{\begin{array}{l}
f(0)=\dot{e}(0)+\lambda e(0) \\
f(\infty) \rightarrow 0 \\
\dot{f}(t) \text { exists }
\end{array}\right.
$$

Specifically, in this paper $f(t)$ is designed as

$$
f(t)=\alpha e^{-\beta t}
$$

where, $\alpha$ and $\beta$ need to be specified. Hence, we can derive the global sliding model control law

$$
\begin{aligned}
Q= & -\widehat{b}(\lambda \dot{\omega}-\dot{f})+\hat{a} \dot{\omega}-\widehat{b} D- \\
& {[\breve{b}|\lambda \dot{\omega}-\dot{f}|+\vec{a}|\dot{\omega}|+C+\breve{b}|D|] \operatorname{sat}(s) }
\end{aligned},
$$

where,

$$
\begin{aligned}
& D=-(\ddot{\tilde{\omega}}+\lambda \dot{\tilde{\omega}}), \\
& \left\{\begin{array}{l}
\widehat{a}=\frac{a_{1}+a_{2}}{2} \\
\breve{a}=\frac{a_{2}-a_{1}}{2},
\end{array}\right. \\
& \begin{cases}\widehat{b}=\frac{b_{1}+b_{2}}{2} \\
\breve{b}=\frac{b_{2}-b_{1}}{2},\end{cases} \\
& \operatorname{sat}(s)= \begin{cases}1 & s / \varepsilon>1 \\
s / \varepsilon & |s / \varepsilon| \leq 1, \\
-1 & s / \varepsilon<-1\end{cases}
\end{aligned}
$$

where, $\varepsilon<1$ is a small positive constant. The saturation function $\operatorname{sat}(s)$ is used to alleviate the chattering of the sliding model surface.

\subsection{The stability proof of the control law}

Theorem 1. As to the uncertain nonlinear system (4) and the global sliding model surface (7), if the gains of the global sliding model control law $Q(10)$ are given by the boundaries of the system uncertainties $a_{1}, a_{2}, b_{1}, b_{2}$ and $C$, then for any uncertain $p(t), h(t)$ and $c(t)$, the error can be made to $\lim (\omega-\widetilde{\omega})=0$.

Proof of Theorem 1. Calculate the differential of $s$ in (7) to yield

$$
\begin{aligned}
\dot{s} & =\ddot{e}+\lambda \dot{e}-\dot{f}=\ddot{\omega}-\ddot{\tilde{\omega}}+\lambda(\dot{\omega}-\dot{\tilde{\omega}})-\dot{f} \\
& =\ddot{\omega}+(\lambda \dot{\omega}-\dot{f})-(\ddot{\tilde{\omega}}+\lambda \dot{\tilde{\omega}})= \\
& =\ddot{\omega}+(\lambda \dot{\omega}-\dot{f})+D= \\
& =-p \dot{\omega}+h Q+h c+(\lambda \dot{\omega}-\dot{f})+D= \\
& =h\left[h^{-1}(\lambda \dot{\omega}-\dot{f})+h^{-1} D-h^{-1} p \dot{\omega}+Q+c\right]
\end{aligned}
$$

Substitute (10) for $Q$ in (15) to yield

$$
\begin{aligned}
& h^{-1} \dot{s}=h^{-1}(\lambda \dot{\omega}-\dot{f})+h^{-1} D-h^{-1} p \dot{\omega}-\widehat{b}(\lambda \dot{\omega}-\dot{f})+\hat{a} \dot{\omega}- \\
& -\widehat{b} D-[\breve{b}|\lambda \dot{\omega}-\dot{f}|+\breve{a}|\dot{\omega}|+C+\breve{b}|D|] \operatorname{sat}(s)+c= \\
& =\left(h^{-1}-\widehat{b}\right)(\lambda \dot{\omega}-\dot{f})-\breve{b}|\lambda \dot{\omega}-\dot{f}| \operatorname{sat}(s)+\left(h^{-1}-\widehat{b}\right) D- \\
& -\breve{b}|D| \operatorname{sat}(s)+\left(\widehat{a}-h^{-1} p\right) \dot{\omega}-\breve{a}|\dot{\omega}| \operatorname{sat}(s)+c-C \operatorname{sat}(s)
\end{aligned}
$$

Let the Lyapunov candidate function be 


$$
V=\frac{1}{2} s^{2} .
$$

Then we can get

$$
\begin{aligned}
h^{-1} \dot{V}= & h^{-1} s \dot{s}=\left(h^{-1}-\widehat{b}\right)(\lambda \dot{\omega}-\dot{f}) s-\breve{b}|\lambda \dot{\omega}-\dot{f}| s \operatorname{sat}(s)+ \\
& +\left(h^{-1}-\widehat{b}\right) D s-\breve{b}|D| s \operatorname{sat}(s)+\left(\widehat{a}-h^{-1} p\right) \dot{\omega} s- \\
& -\breve{a}|\dot{\omega}| s \operatorname{sat}(s)+c s-C s \operatorname{sat}(s)
\end{aligned}
$$

Refer to (5), (12) and (13) we can get

$$
\left\{\begin{array}{l}
\left(h^{-1}-\bar{b}\right) \leq \breve{b} \\
\left(\widehat{a}-h^{-1} p\right) \leq \breve{a}
\end{array} .\right.
$$

\section{Considering (11) and (14) it suggests}

$s \leq s \operatorname{sat}(s)$

Hence

$$
\left\{\begin{array}{l}
\left(h^{-1}-\widehat{b}\right)(\lambda \dot{\omega}-\dot{f}) s-\breve{b}|\lambda \dot{\omega}-\dot{f}| s \operatorname{sat}(s) \leq 0 \\
\left(h^{-1}-\widehat{b}\right) D s-\breve{b}|D| s \operatorname{sat}(s) \leq 0 \\
\left(\widehat{a}-h^{-1} p\right) \dot{\omega} s-\breve{a}|\dot{\omega}| s \operatorname{sat}(s) \leq 0 \\
c s-C s \operatorname{sat}(s) \leq 0
\end{array}\right.
$$

That is

$\dot{V} \leq 0$

(22) indicates that for any given uncertain $p(t), h(t)$ and $c(t)$, the control system is asymptotically stable. Hence, this completes the proof.

\section{Determine the boundary of model uncertainty}

It is noticeable in Theorem 1 that to a certain degree the stability of the control system relies on the system uncertain parameters $p(t), h(t)$ and $c(t)$. Since parameters $p(t)$ and $h(t)$ are usually involved with the actual coefficients of the propulsion system, they could be predicted by prior experience and professional knowledge according to the system coefficients. However, the uncertain parameter $c(t)$ is induced by the external unknown excitations of the wave loads and hence it is difficult to estimate it by prior experience and professional knowledge. It is believed that the modeling uncertainty $c(t)$ will significantly influence the accuracy of the possible responses of the control system. To well compensate the external perturbation $c(t)$, both experimental investigation and sea trial have been carried out in this paper to determine the uncertainty upper boundary $C$ to ensure the control stability and control performance.

\subsection{Experiments}

The experiments have been carried out on a marine shaft-line test-bed to investigate the influence of wave loads on the engine power transfer. Fig. 1 shows the overall of the experimental system. The system consists of a drive motor and the speed controller, a crank set, a marine shaft line with three support bearings, a wave loading system on the end of the shaft line, and a signal acquisition system. The wave loading system can simulate the varying wave loads from vertical, horizontal and axial directions. The signal acquisition system adopts the Kongsberg Shaft Power Meter (MetaPower) to measure the shaft torque and power transferred from the main engines to the propellers [23].
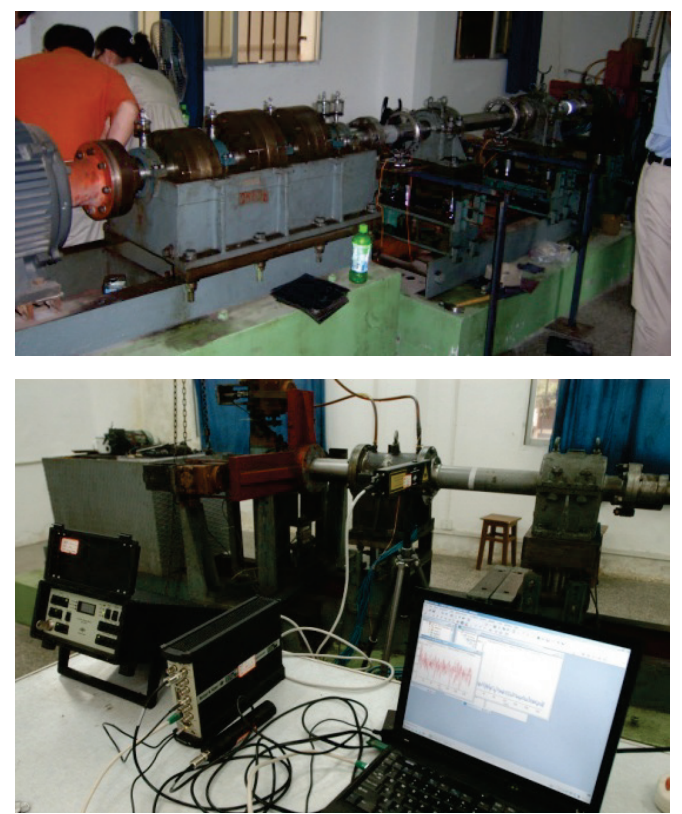

Figure 1 The overall of the experimental system
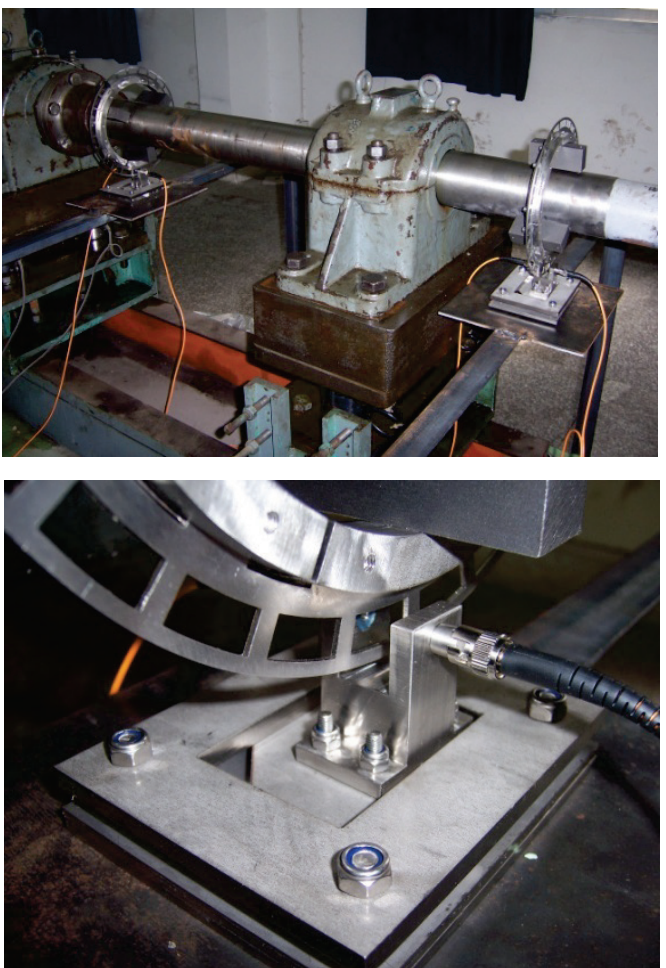

Figure 2 The MetaPower system for signal collection 
Fig. 2 shows the MetaPower system. The MetaPower system adopts two optical-fibers to transmit light signal to on-line detect the torsion of shaft and calculate the torque and power values.
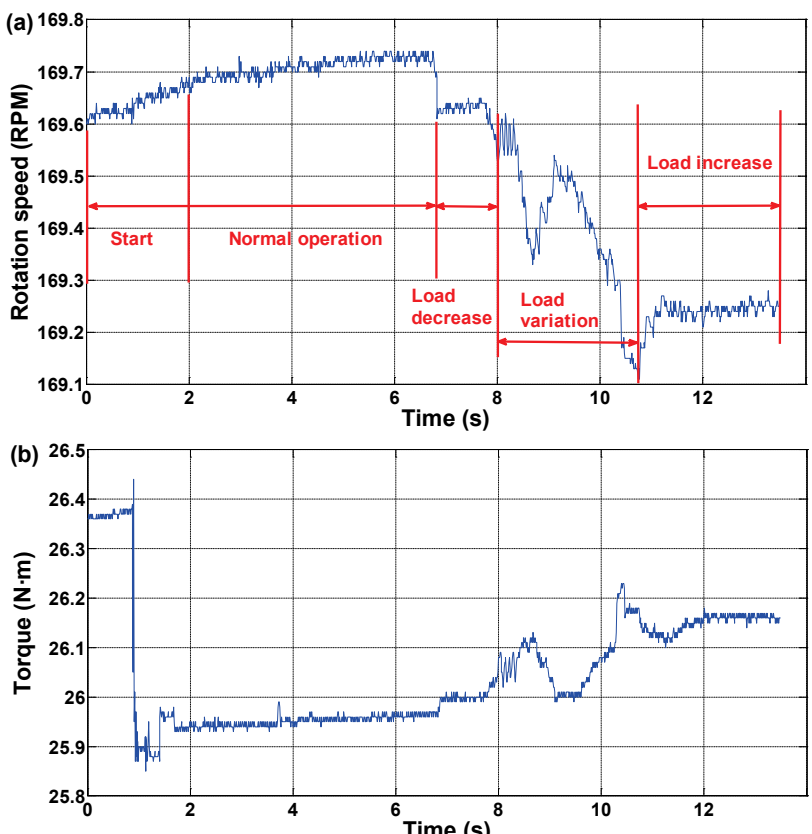

Figure 3 The power fluctuation of the propulsion system under load variation condition: (a) the speed fluctuation and (b) the torque fluctuation
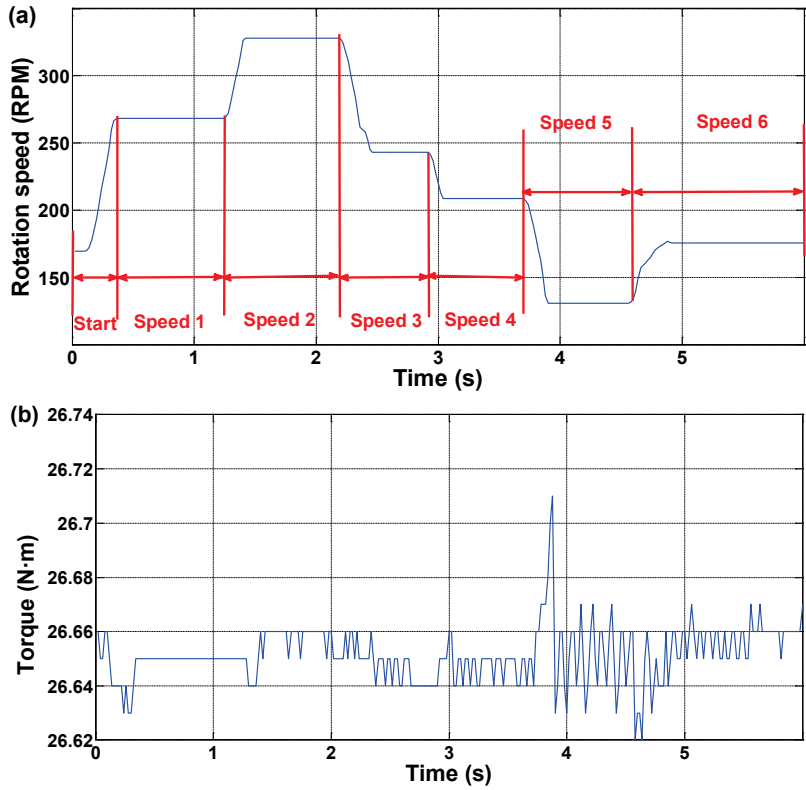

Figure 4 The power fluctuation of the propulsion system under speed variation condition: (a) the speed fluctuation and (b) the torque fluctuation

In order to investigate the uncertainty upper boundary $\mathrm{C}$, we have discussed the influence of the load and speed variations on the engine power transfer in the experiments. This is because the interaction between the shaft line and wave loads is dual. The variation of the wave loads will influence the shaft speed while the variation of the shaft speed will influence the wave loads. Fig. 3 shows the power fluctuation of the propulsion system under speed variation condition and Fig. 4 shows the power fluctuation of the propulsion system under load variation condition.

The analysis result in Fig. 3 shows that the torque fluctuation of the shaft line is obviously influenced by the load variation. The engine torque loss could reach to 1,04 $\%$ of the input power according to the calculation result using MetaPower.

The analysis result in Fig. 4 shows that the torque fluctuation of the shaft line could be influenced by the speed variation but not that strong as the load variation. The engine torque loss could reach $0,24 \%$ of the input power according to the calculation result using MetaPower.

\subsection{Sea trial}

The sea trial for the shipboard measurement is carried out in a 67300 Tons bulk carrier named "Anguo Shan". The ship parameters of "Anguo Shan" are listed in Tab. 1. The environment parameters in the sea trial are listed in Tab. 2. The torque meter is installed on the shaft to measure the shaft power under different engine load conditions. The measurements are shown in Fig. 5.

It can be seen in Fig. 5 that the engine power fluctuation is influenced by the load condition greatly. The maximum engine power fluctuation rate of $50 \%, 75$ $\%, 90 \%$ and $100 \%$ load conditions could reach $1,85 \%$, $1,52 \%, 1,13 \%$, and $0,66 \%$ of the engine power, respectively. Compared with the experimental test results, the power fluctuation of the propulsion system in sea trial is larger than that of the experimental tests. This is because the wave loads in the real sea are more complex than the simulated ones in the experiments. However, in the load variation tests in the experiment the maximum engine power loss rate is $1,04 \%$, which is close to the sea trial results. Hence, the experiment tests could correctly and reliably simulate the dynamics of the marine propulsion system subjected to the coupled effect of the wave loads, hull and the propulsion dynamics. As a result, a fiducial upper boundary of $1,85 \%$ of the engine power loss can be determined for the model uncertainty $c(t)$.This uncertainty upper boundary will be incorporated into the GSMC to provide robust control performance of the ship speed governor.

Table 1 The "Anguo Shan" ship parameters

\begin{tabular}{|c|c|c|c|}
\hline Dimension & $\mathrm{m}$ & Main engine & Propeller \\
\hline Length & 200 & $\begin{array}{c}\text { Model: } \\
\text { MAN B\&W 6S50MCC }\end{array}$ & $\begin{array}{c}\text { Type: } \\
\text { Fixed pitch }\end{array}$ \\
\hline Width & 32,3 & $\begin{array}{c}\text { Rated power: } \\
8510 \mathrm{~kW} \times 114 \mathrm{rev} / \mathrm{min}\end{array}$ & $\begin{array}{c}\text { Number of } \\
\text { blades: } 5\end{array}$ \\
\hline $\begin{array}{c}\text { Designed } \\
\text { draft }\end{array}$ & 11,7 & $\begin{array}{c}\text { Intermediate shaft } \\
\text { diameter: } 450 \mathrm{~mm}\end{array}$ & \\
\hline
\end{tabular}

Table 2 The environment parameters in the sea trial

\begin{tabular}{|l|c|}
\hline \multicolumn{1}{|c|}{ Trial condition } \\
\hline Location & The east China sea \\
\hline Wind speed & $3 \div 4 \mathrm{MPH}$ \\
\hline Depth of water & $60 \mathrm{~m}$ \\
\hline Temperature of sea water & $21^{\circ} \mathrm{C}$ \\
\hline Fore draft & $8,0 \mathrm{~m}$ \\
\hline Aft draft & $9,0 \mathrm{~m}$ \\
\hline
\end{tabular}




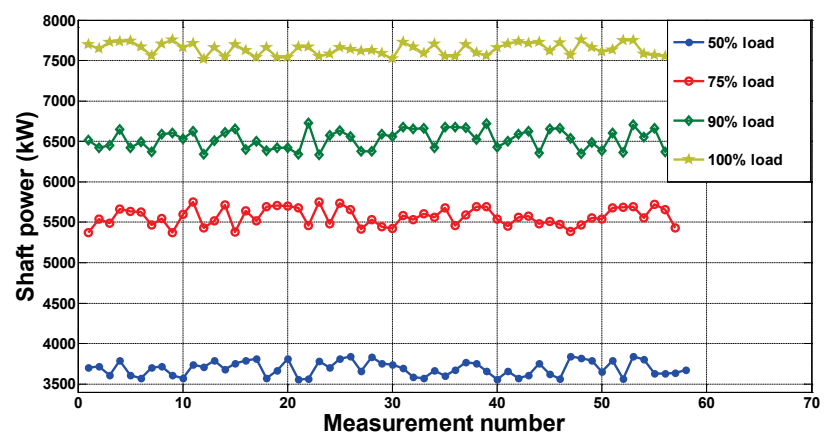

Figure 5 The measurements of the "Anguo Shan" ship in the sea trial

\section{Conclusion}

The coupled effect between the water, ship hull and propulsion system has been increasing with the rapid increase of the size of the marine vessels to threaten the control efficiency of the ship speed governors. Alternative nonlinear control methodology is crucial for high performance control of the marine propulsion system under uncertainty. The global sliding model control (GSMC) technique enables one to design a robust controller against system uncertainties in a practical way. However, before designing the GSMC controller for the marine propulsion system it needs to handle the uncertainty boundary problem. The contribution of this work is that for the first time the uncertainty boundaries of the marine propulsion system under interaction between the water, ship hull and propulsion has been investigated by both experiments and sea trials. The analysis results demonstrate that a fiducial upper boundary of $1,85 \%$ was characterised to the model uncertainties of the GSMC model. Based on this finding, a robust nonlinear controller could be developed to enhance the ship control performance against the waterhull-propulsion interaction.

Further, we have investigated the control performance of the proposed robust GSMC model in Part 2: Controller Validation.

\section{Acknowledgements}

This research was funded by the Key Program of National Natural Sciences Foundation of China (NSFC) (No. 51139005), the National Basic Research Program of China (973 Program) (No. 2014CB046303), the China Postdoctoral Science Foundation (No.2014M551687), the Science Foundation of Jiangsu Province (No. BK20140200), the Postdoctoral Science Foundation of Jiangsu Province (No. 1402053B), the State Foundation for Studying Abroad from China Scholarship Council (NO. 201406425014), the Tribology Science Fund of State Key Laboratory of Tribology (No. SKLTKF14B05) and the Priority Academic Program Development of Jiangsu Higher Education Institutions.

\section{References}

[1] Li, Z.; Yan, X.; Qin, L.; Yuan, C.; Peng, Z. Model reference robust control for marine propulsion systems with model uncertainty caused by hull deformation. // Journal of Marine Science and Technology. 21, 4(2013), pp. 400-409.
[2] Schulten, P. The Interaction between diesel engine, ship and propeller during manouevring. / $\mathrm{PhD}$ thesis, Technische Universiteit Delft, Delft, Netherlands, 2005.

[3] Yan, X.; Li, Z.; Yuan, C.; Zhu, H.; Liu, Z. Modelling and control of marine propulsion system coupled with hull deformation. // Ship and Ocean Engineering. 40, 1(2011), pp. 60-63.

[4] Khaled, N.; Chalhoub, N. G. A dynamic model and a robust controller for a fully actuated marine surface vessel. // Journal of Vibration and Control. 17, 6(2011), pp. 801-812.

[5] Brzózka, J. Analysis of nonlinear model following control/internal model control (MFC/IMC) structure for a ship engine speed control. // Systems Science. 34, 3(2008), pp. 25-29.

[6] Xiros, N. PID marine engine speed regulation under full load conditions for sensitivity H-norm specifications against propeller disturbance. // Proceedings of the Institute of Marine Engineering, Science and Technology Part A: Journal of Marine Engineering and Technology. 5, (2004), pp. 3-11.

[7] Zhangand, G.; Ren, G. Hardware-in-loop simulation of ship speed hybrid error regulator and its stability analysis. // Journal of System Simulation. 22, 2(2010), pp. 353-357.

[8] Su, S.; Zhang, W.; Wang, Y.; Liu, L.; Tian, Z.; Li, G.; Liu, B. Calculation and analysis of nonlinear dynamics of propulsion system with external load. // Shipbuilding of China. 53, 1(2012), pp. 79-86.

[9] Du, J.; Guoand, C.; Yu, S. Adaptive robust nonlinear ship course control based on backstepping and Nussbaum gain. // Intelligent Automation and Soft Computing. 13, 3(2007), pp. 263-272.

[10] Liu, W.; Sui, Q.; Xiao, H.; Zhou, F. Sliding backstepping control for ship course with nonlinear disturbance observer. // Journal of Information and Computational Science. 8, 16(2011), pp. 3809-3817.

[11] Witkowska, A.; Tomera, M. A backstepping approach to ship course controller. // The International Journal of Applied Mathematics and Computer Science. 17, 1(2007), pp. 73-85.

[12] Hu, S.; Yang, P.; Juang, J. Robust nonlinear ship coursekeeping control by $\mathrm{H} \infty \mathrm{I} / \mathrm{O}$ linearization and $\mu$-synthesis. // International Journal of Robust and Nonlinear Control. 13, 1(2003), pp. 55-70.

[13] Fossen, T. A Survey on nonlinear ship control: From theory to practice. // Proceedings of the $5^{\text {th }}$ IFAC Conference on Manoeuvering and Control of Marine Craft, Aalborg, Denmark, 2000.

[14] Fossen, T. A nonlinear unified state-space model for ship maneuvering and control in a seaway. // International Journal of Bifurcation and Chaos. 15, (2005), pp. 2717 2745.

[15] Zhangand, G.; Ren, G. Model free adaptive control of marine autopilot. // Ship Engineering. 30, 1(2008), pp. 3740.

[16] Fang, M.; Luo, J. On the track keeping and roll reduction of the ship in random waves using different sliding mode controllers. // Ocean Engineering. 34, (2007), pp. 479-488.

[17] Moreira, L.; Fossen, T.; Guedes, C. Path following control system for a tanker ship model. // Ocean Engineering. 34, (2007), pp. 2074-2085.

[18] Le, M.; Tran, Q.; Nguyen, T.; Gap, V. Control of large ship motions in harbour maneuvers by applying sliding mode control. // In: $8^{\text {th }}$ IEEE International Workshop on Advanced Motion Control, 2004, pp. 695-700.

[19] Yuan, L.; Wu, H. Simulation and design of fuzzy slidingmode controller for ship heading-tracking. // Journal of Marine Science and Application. 10, 1(2011), pp 76-81.

[20] Zhangand, G.; G. Ren, Research on ship speed regulator using on-line adaptive error model. // Chinese Internal Combustion Engine Engineering. 30, 1(2009), pp. 88-92. 
[21] Zhangand, G.; Ren, G. Research on ship diesel engine speed regulator using on-line learning and self-tuning error model. // Transactions of CSICE. 27, 3(2009), pp. 259-264.

[22] Zhangand, G.; Ren, G. Hybrid prediction control model of ship's track. // Journal of Traffic and Transportation Engineering. 7, 6(2007), pp. 41-45.

[23] Qin, Li; Zhou, Xincong; Gao, Yan; Cao, Pengju; Quan, Jianzhou; Li, Zhixiong. Shaft power measurement for marine propulsion system based on magnetic resonances. // IEICE Electronics Express. 9, 15(2012), pp. 1260-1265.

[24] Wai, R.; Chuang, K.; Lee, J. On-line supervisory control design for maglev transportation system via total slidingmode approach and particle swarm optimization. // IEEE Transactions on Automatic Control. 55, 7(2010), pp. 15441559.

\section{Authors' addresses}

Zhixiong Li, PhD

School of Mechatronic Engineering, China University of Mining \& Technology, Xuzhou 221116, China

Jiangsu Key Laboratory of Mine Mechanical and Electrical Equipment, China University of Mining \& Technology, Xuzhou 221116, China

State Key Laboratory of Tribology, Tsinghua University, Beijing 100000, China

School of Mechanical \& Manufacturing Engineering, University of New South Wales, NSW 2052 Sydney, Australia

\section{Xinping Yan, Prof. PhD}

School of Energy \& Power Engineering, Wuhan University of Technology, Wuhan 430063, China

Email: lzx_520@163.com

\section{Li Qin, PhD}

School of Machinery \& Automation, Wuhan University of Science and Technology, Wuhan 430081, China

\section{Kai Cheng, PhD}

School of Energy \& Power Engineering, Wuhan University of Technology, Wuhan 430063, China

\section{J. T. Xing, Prof. PhD}

WUT-UOS High Performance Ship Technology Joint Centre, Wuhan 430063, China

Faculty of Engineering \& the Environments, University of

Southampton, Southampton, SO17 1BJ, UK 